\title{
The Relationship between Private Tutoring and Academic Achievement - An Application of a Multivariate Latent Growth Model -
}

The study examined how changes in time invested in private tutoring and academic achievement influenced each other through a multivariate latent growth model by using the data from the first to the third year presented in the KYPS. This study identifies not only how changes in the private tutoring experience exerted a direct influence on changes in academic achievement, but also measures what kind of changes in private tutoring and academic achievement had emerged over time. The detailed study results are as follows. First, the analysis of time invested in private tutoring showed that the higher the grades, the greater were the amount of time invested in private tutoring in the case of Korean language study. On the other hand, the results showed that in the case of English and mathematics, the higher the grades, the lesser was the amount of time invested in private tutoring. Second, private tutoring and academic achievement were all in a linear relationship. Third, it was shown that the time invested in private tutoring and academic achievement exerted a negative influence on each other according to the passage of time.

\section{INTRODUCTION}

Private tutoring is a widespread phenomenon found in most advanced countries. A comparative analysis of 41 countries by Baker et al. (2001) showed that one out of three students, and more than $40 \%$ of students in Asian countries such as Korea and Japan,

Assistant Professor, Jeonju University, 1200 3-ga Hyoja-dong, Wansan-gu, Jeonju 560-756, Korea (bluesj@jj.ac.kr)

Key Words: private tutoring, academic achievement, multivariate latent growth model, longitudinal analysis, KYPS and Eastern European countries such as Russia and the Czech Republic, had participated in private tutoring. Baker and LeTendre (2005) analyzed the state and causes of private tutoring in many countries, emphasizing that the phenomenon of private tutoring had spread regardless of differences in students' characteristics or backgrounds. The spread of private tutoring has also emerged as a social problem because it not only strengthens the existing deprivation between regions and classes but also has the possibility of creating new differences in educational achievement caused by educational gaps.

The private tutoring issue is one of the difficult issues that have remained unsolved for a long time. Even though the Korean government has mobilized sizable budgets and administrative capacities to reduce private tutoring that had been occurring for decades, the participation rate and amount of spending for private tutoring has consistently increased. According to the results of a "Survey on private tutoring" conducted by the National Statistical Office, $87.4 \%$ of elementary school students, $74.3 \%$ of middle school students, and $62.8 \%$ of high school students participated in private tutoring in 2009. In particular, the difference of participation rate and spending for private tutoring between income classes and regions has grown (Statistics Korea, 2009).

Private tutoring is considered part of the social climate and taken for granted throughout people's entire school life (Nam, 2008). Thus, people feel anxiety about falling behind the competition or being at a disadvantage if they do not use private tutoring. Accordingly, this became the major driving 
force pushing people into private tutoring (Lee, 2007).

However, it is difficult to conclude that the phenomenon of private tutoring resulted directly from anxiety (Shon et al., 2010). If there was no significant relation between private tutoring and students' academic achievement or a better chance at acceptance into a higher grade school, the private tutoring issue would not have lasted as long as it has. Finally, the issue of private tutoring has led to expectations that it might exert positive effects on real educational achievement.

Existing studies on educational achievement in private tutoring have commonly shown that the rates of those who had experienced private tutoring have consistently increased and that there was a change in the participation rate and spending required for private tutoring according to educational level (Shin \& Kim, 2010; Park, 2010; Lee \& Kwon, 2011). However, no previous study has carried out a systematic approach to measure the continuous effects of private tutoring and the direct influence that it has played on academic achievement. Even if private tutoring could consistently exert influence on academic achievement, a considerable number of studies have been conducted only on data from a single point in time (Kim, 2007)

Previous studies of the impact of private tutoring on student achievement have four limitations. First, they have not sufficiently considered the longitudinal impact of private tutoring on student achievement by using cross-sectional data. In order to consider the impact of different types of private tutoring on different types of student achievement, a longitudinal analysis of this impact would be necessary. Second, previous studies tended to focus on spending on private tutoring instead of the amount of time spent being tutored. This amount of time should be taken into account because to obtain higher achievement, the student should organize private tutoring time effectively as a part of his or her study time. Third, previous studies have interpreted the correlation between private tutoring and student achievement in terms of the impact of private tutoring on student achievement, as shown in the literature review; however, studies should also take into consideration the impact of student achievement on private tutoring (Kim, 2007; Lee, 2007; Nam, 2008).

This study examined the influence on changes in private tutoring and academic achievement through a multivariate latent growth model for Korean students who had a relatively high dependence on private tutoring to supplement their learning and address the problems mentioned above. Specifically, this study attempted to measure the time invested in private tutoring for the subjects of Korean, mathematics, and English, and to use objective data about academic achievement in order to examine systematically the relationship between the time invested in private tutoring and academic achievement.

This study identifies not only how changes in the private tutoring experience exerted a direct influence on changes in academic achievement, but also measures what kind of changes in private tutoring and academic achievement had emerged over time.

\section{LITERATURE REVIEW}

\section{Definition of Private Tutoring}

It is quite difficult to reach a consensus on a definition of private tutoring. For example, Lee (2007) defines it loosely as the form of out-of-school supplementary education for remediation and enrichment purposes. Bray and Kwok (2003) change these dimensions slightly. They remove the dimension of supplementation and consider private tutoring "additional to the provision by mainstreaming schooling." In addition, private supplementary tutoring should be provided outside of school hours. Finally, they change the term privateness into financial gain. Other educational models are similar to private tutoring. Some scholars examine shadow education (Baker et al., 2001; Baker \& LeTendre, 2005; Bray, 2006; Lee, 2007; Stevenson \& Baker, 1992). Shadow education involves "a set of educational activities outside formal schooling that are designed to improve a student's chances of successfully moving through the allocation process" (Stevenson \& Baker, 1992). However, shadow education could have some negative connotations because of the word "shadow." In some Englishspeaking countries, private tuition is used instead of 
private tutoring (Foondun, 2002; Ireson, 2004; Smyth, 2009). Private tuition is "extra coaching in academic and examinable subjects that is given to students outside school hours for remuneration" (Foondun, 2002, p. 487).

The common factor in these definitions of private tutoring, shadow education, and private tuition is the idea of education outside of school hours. Therefore, we considered all learning activities out of school as private tutoring in this paper.

\section{Theoretical Approaches to Private Tutoring}

The theoretical frameworks on private tutoring can be divided into three categories: human capital theory, status competition theory, and theories from an institutional standpoint. In human capital theory, if people learn economically valuable knowledge, skills, and creativity through education or training, their productivity increases and thus they can obtain better results (Baker, 1993). Specifically, education, both formal and non-formal, is considered the most important action to accumulate human capital in human capital theory. According to this perspective, private tutoring can become a valuable method of accumulating human capital (Paik, 1999). In other words, private tutoring is understood as an investment rather than from the perspective of consumption in human capital theory.

In status competition theory, private tutoring is explained as a means of competition to acquire a higher social status, not as a means to improve productivity. People tend to invest in education to obtain higher levels of education because level of education is recognized as an important means to acquire an elevated social status. As a result, the level of education has continuously increased and schools tend to compete with each other to send more students to higher grade and prestigious schools. However, when competition related to education intensifies in this way, parents spare nothing when investing in their children's education and this increases the demand for private tutoring (Dore, 1976).

From an institutional standpoint, the demand for private tutoring does not simply result from the competition to acquire a higher status. On the contrary, the climate in which private tutoring is taken for granted encourages private tutoring (Baker \& LeTendre, 2005; Baker et al., 2001). From this perspective, members make use of private tutoring because private tutoring is taken for granted by the institution.

\section{The Relation between Private Tutoring and Academic}

\section{Achievement}

There is an ongoing debate about the influence of private tutoring on academic achievement. In previous studies, analyses have been performed with individual sampling methods in the early 2000s. Later, studies began using international achievement data, such as TIMSS (Trends in International Mathematics and Science Study) or PISA (Program for International Assessment) (Yang \& Kim, 2003; Nam, 2008), and longitudinal data (e.g., Korea Youth Panel, Korean Education \& Employment Panel, Korean Education Longitudinal Study) (Park \& Do, 2005; Lee, 2006; Kim, 2007; Lee \& Im, 2009; Kang \& Lee, 2010).

The results of these studies on the relation between private tutoring and achievement were not consistent. For example Hahn et al. (2001) analyzed a survey conducted for $11^{\text {th }}$ grade students and found that the achievement of students who had received private tutoring was not statistically significant. Moreover, the independent effects of private tutoring were not verified even after variables such as home backgrounds, personal characteristics, gender, and region were controlled. Kim (2007) analyzed the Korean Education and Employment Panel and revealed that expenses paid for private tutoring had no statistically significant influence on the results of the College Scholastic Ability Test.

Other studies have shown that private tutoring exerted a partial effect on achievement, but the influence was not systematic. Lee (2002) showed that there was a partial effect of private tutoring on English even though the effect of private tutoring was not verified in subjects such as Korean and mathematics. Yang and Kim (2003) showed that private tutoring had an influence on achievements in mathematics, whereas private tutoring had a statistically significant influence on achievements in 
mathematics in all of the studies performed by Lee (2006), Park (2010), and Lee and Im (2009). On the other hand, Ban et al. (2005) found a negative relation between private tutoring and academic achievement by analyzing the relations between variables related to private tutoring, specifically the amount of time and expenses invested into private tutoring, and academic achievement, using the Korean Education \& Employment Panel. Finally, it was shown that the influence of private tutoring on academic achievement differed by a small degree according to subject.

Several recent analyses for other Asian countries report mixed findings regarding the impact of private tutoring. Suryadarma et al. (2006), in a study of Indonesian fourth graders, do not find any significant effect of tutoring on mathematics or dictation results. By contrast, Dang (2007) concludes that private tutoring has a significant positive effect on the achievement of Vietnamese primary and secondary students. Achievement, in this study, is construed as the student's position in the school academic ranking. An analysis by Ono (2007), applied to the ronin phenomenon (by which Japanese students receive an additional year of private education in order to prepare for college entrance examinations), shows how the probability of accessing an elite university is positively affected by this additional education. Ono's study, however, is limited by the fact that only a small set of variables referring to family background, personal and school characteristics is controlled for in the analysis. Finally, mention should be made of the empirical analysis carried out by Banerjee et al. (2007) of private tutoring in India in which, through a randomized experiment, the authors conclude that tutoring has a significant positive effect on achievement.

Studies on the effects of private tutoring showed inconsistent and mixed results. The main reason for this phenomenon was mostly methodological problems related to the data and analytical method (Sung \& Kim, 2010). Even if achievements at the initial level had to be controlled to examine the effects of private tutoring systematically, this problem was not solved because most studies employed a cross-sectional analysis. It is necessary to design a longitudinal study to capture the influence of student backgrounds, pre-achievement variables, and school variables in order to analyze the unique effects of private tutoring on the improvement of academic achievement. This study applied a multivariate latent growth model, one of the longitudinal analysis methods used in the KYPS (Korea Youth Panel Survey), to the data from the national unit to verify the influences of private tutoring on achievement. The detailed research questions posed by this study are as follows:

$<$ Research question 1> How does the amount of time spent in private tutoring change over time?

$<$ Research question 2> How does academic achievement change over time?

$<$ Research question 3> What is the relationship between the amount of time spent in private tutoring and academic achievement?

\section{METHODOLOGY}

\section{Data and Sample}

This study was based on data from the KYPS. This survey captured longitudinal data of the 8th grade, collected from 2003 to 2005, which was the year after the students graduated from middle school. This survey was sponsored by the National Youth Policy Institute. These data were sampled by using the stratified multi-stage cluster sampling based on the principle of the multiple-point prospective panel design. In this study, data from 2003 until 2007 were used. More specifically, the number of the subjects in this study for each year was 3,449 in 2003, 3,188 in 2004, and 3,125 in 2005. This number was different each year because of missing data.

The longitudinal study model of the KYPS was based on a multiple-point prospective panel design whereby the same sample was repeatedly investigated more than three times at different points. In the demographic information for these subjects shown in $<$ Table $1>$, the proportion of males and females was the equal, but urban areas were included more frequently than rural areas. As for the level of fathers' 
Table 1. Description of Sample $(n=3,125)$

\begin{tabular}{|c|c|c|c|c|}
\hline & & \multicolumn{3}{|c|}{ Frequency (\%) } \\
\hline \multirow{2}{*}{ Sex } & Male & \multicolumn{3}{|c|}{$1725(50 \%)$} \\
\hline & Female & \multicolumn{3}{|c|}{$1724(50 \%)$} \\
\hline \multirow{2}{*}{ Area } & Metropolis & \multicolumn{3}{|c|}{$2992(86.7 \%)$} \\
\hline & Countryside & \multicolumn{3}{|c|}{$457(13.3 \%)$} \\
\hline \multirow{4}{*}{ Father's education level } & Middle school & \multicolumn{3}{|c|}{403 (11.9) } \\
\hline & High school & \multicolumn{3}{|c|}{$1481(43.8)$} \\
\hline & Under. graduate & \multicolumn{3}{|c|}{$1260(37.3)$} \\
\hline & Over. graduate & \multicolumn{3}{|c|}{$236(7.0 \%)$} \\
\hline & & \multicolumn{3}{|c|}{ Mean (S.D.) } \\
\hline & & $8^{\text {th }}$ grade & $9^{\text {th }}$ grade & $10^{\text {th }}$ grade \\
\hline \multicolumn{2}{|c|}{ Private tutoring expenses per month ${ }^{1)}$} & $26.07(26.88)$ & $26.65(30.25)$ & $27.10(33.71)$ \\
\hline
\end{tabular}

1) $\mathrm{Unit}=\mathrm{KRW}$

education, $80 \%$ had lower than a college education and high school education. The monthly average of expenses for private tutoring was 260.7 thousand won in the first year, 266.5 thousand won in the second year, and 271 thousand won in the third year.

\section{Variables}

This study measured the average times per week invested in private tutoring as a way to examine the changes in private tutoring. The study used the average value, which was calculated by adding the time invested into seven areas of private tutoring such as group tutoring, courses in private-tutoring institutions, tutoring with study worksheets, internet tutoring, after-school tutoring in school, and overseas training to the subject expected to exert the most important influence on academic achievement. The study converted the overall ranking into a percentage in terms of academic achievement where the larger the number, the greater is the academic achievement.

\section{The Model for Analysis}

This study applied a multivariate latent growth model to examine the relationship between changes in the time invested in private tutoring and changes in academic achievement. This statistical technique allows estimating of individual growth curves that represent change or growth in language the time invested in private tutoring and changes in academic achievement. With linear growth curves, two growth parameters are estimated, namely an initial level growth parameter (i.e., intercept) and a growth rate parameter (i.e., slope). These parameters are viewed as latent variables, and these latent variables can be estimated using structural equation model. Both parameters vary between individuals, meaning that for each individual a growth curve is estimated with a specific initial status and a specific rate of change.

It is important in longitudinal research to maintain the sampling numbers. In this case, $86 \%$ of the subjects, 2,967 of 3,449 , continued to participate in the study for five years. Therefore, the percentage of the missing was $14 \%$. Therefore, the parameters of interest were estimated by using FIML (fullinformation maximum likelihood). Because the FIML estimate uses all the information in the observed data, including the information about the missing portions of a variable, this method gives the least-biased estimates in AMOS (Arbuckle, 2005).

The FIML is analyzed in the following two stages in order to verify the relationship among the various variables over time. In the first stage, competitive models of a latent growth model (linear and quadratic functions) are based on individual variables in order to compare and analyze. In the second stage, after the optimal model is found for individual variables, these models are combined (Choi, 2011). This study 
Table 2. Results of Each Variable's Model Suitability

\begin{tabular}{llccccc}
\hline & \multicolumn{1}{c}{ Model } & $\chi^{2}$ & df & CFI & TLI & RMSEA \\
\hline \multirow{3}{*}{ Private tutoring } & No growth model & 8.216 & 6 & .956 & .956 & .010 \\
& Linear model $(0,1,2)$ & 600.938 & 3 & .927 & .921 & .024 \\
& Linear model $(0,1,1)$ & 712.932 & 3 & .959 & .918 & .026 \\
\hline \multirow{2}{*}{ Academic achievement } & Linear model $(\mathbf{0 , 0 , 1 )}$ & $\mathbf{3 . 4 8 4}$ & $\mathbf{3}$ & $\mathbf{. 9 9 0}$ & $\mathbf{. 9 8 1}$ & $\mathbf{. 0 0 7}$ \\
& No growth model & 948.356 & 6 & .680 & .680 & .213 \\
& Linear model & 900.938 & 3 & $\mathbf{. 9 7 9}$ & $\mathbf{. 9 7 8}$ & $\mathbf{. 0 2 4}$ \\
\hline
\end{tabular}

Table 3. Descriptive Statistics of Private Tutoring and Academic Achievement

\begin{tabular}{|c|c|c|c|c|}
\hline & & \multicolumn{3}{|c|}{ Mean (S. D.) } \\
\hline & & $8^{\text {th }}$ grade & $9^{\text {th }}$ grade & $10^{\text {th }}$ grade \\
\hline \multirow{4}{*}{ Private $^{1)}$ tutoring } & Korean & $3.06(1.67)$ & $3.18(1.56)$ & $3.33(1.80)$ \\
\hline & English & $4.08(2.35)$ & $4.06(2.32)$ & $3.81(2.12)$ \\
\hline & Math & $4.05(2.37)$ & $4.10(2.19)$ & $4.10(2.40)$ \\
\hline & $($ Korean + English + Math $) / 3$ & $3.79(1.73)$ & $3.81(1.69)$ & $3.82(1.93)$ \\
\hline \multicolumn{2}{|c|}{ Academic achievement ${ }^{2)}$} & $58.26(27.15)$ & $60.58(26.58)$ & $63.33(24.93)$ \\
\hline
\end{tabular}

1) hours per week, 2) overall ranking into a percentage

compared the suitability of a no-change model and a linear model with variables to identify the optimal growth model regarding individual variables in the first stage. A linear model is composed of slope factors representing the rate of change over time and the repeated measure is used as a multiple indicator for two related potential factors. By comparing the suitability of the model after fixing $(0,1,2),(0,1,1)$, and $(0,0,1)$ to the slope (since changes over time were not significant in terms of time invested in private tutoring), results showed that the suitability of the model fixed on $(0,0,1)$ was the best. The suitability of the concrete model is shown in $<$ Table $2>$.

\section{RESULTS}

\section{Descriptive Statistics of Private tutoring and Academic Achievement}

Descriptive statistics of private tutoring and academic achievement are shown in $<$ Table $3>$. As for the time invested in Korean language courses in private tutoring, a direct correlation was found between time invested and higher grades-that is, the higher the grade, the greater was the amount of time invested in private tutoring. The time invested in Korean language tutoring was 3.06 hours in the first year, 3.18 hours in the second year, and 3.33 hours in the third year. The time spent on English tutoring was different from that spent on Korean. For English tutoring, the higher the grade, the lesser was the amount of time spent on tutoring. The average time invested in English was 4.08 hours in the first year, 4.06 hours in the second year, and 3.81 hours in the third year. In the case of mathematics, the time invested in private tutoring had decreased between $8^{\text {th }}$ graders and $9^{\text {th }}$ graders, but there was no change between $9^{\text {th }}$ graders and $10^{\text {th }}$ graders. Overall, the average time invested in private tutoring including Korean, English, and mathematics had increased slightly, showing 3.79 hours in the first year, 3.81 hours in the second year, and 3.82 hours in the third year. Academic achievement had increased. More specifically, achievement was 58.26 in $8^{\text {th }}$ graders, 60.58 in $9^{\text {th }}$ graders, and 63.33 in $10^{\text {th }}$ graders.

The analysis of time invested in private tutoring showed that the higher the grades, the greater were the amount of time invested in private tutoring in the case of Korean language study. On the other hand, the results showed that in the case of English 
Table 4. Estimates of the Latent Growth in Measurement Model

\begin{tabular}{lccccc}
\hline \multirow{2}{*}{ Variable } & \multicolumn{2}{c}{ Mean } & \multicolumn{2}{c}{ Variance } & \multicolumn{2}{c}{ Covariance } \\
\cline { 2 - 6 } & \multicolumn{1}{c}{ Intercept } & Slope & Intercept & Slope & Inter-slope \\
\hline Private tutoring & $3.797(.036)^{* * *}$ & $.002(.034)^{*}$ & $.591(.129)^{* * *}$ & $.168(.092)^{*}$ & $-.112(.089)$ \\
Academic achievement & $57.3871(.501)^{* * *}$ & $1.929(.278)^{* * *}$ & $638.948(21.167)^{* * *}$ & $94.757(6.810)^{* * *}$ & $-.149 .063(.278)^{* * * *}$ \\
\hline
\end{tabular}

Table 5. Estimation of Multivariate Latent Growth Model

\begin{tabular}{lc}
\hline & Estimation (SE) \\
\hline Intercept of private tutoring $\leftrightarrow$ Intercept of academic achievement & $12.282(.633)^{* * *}$ \\
Slope of academic achievement $\leftarrow$ Intercept of private tutoring & $-3.700(.282)^{* * *}$ \\
Slope of private tutoring $\leftarrow$ Intercept of academic achievement & $-.011(.001)^{*}$ \\
\hline
\end{tabular}

and mathematics, the higher the grades, the lesser was the amount of time invested in private tutoring. Even though the results revealed that the total average time invested in private tutoring in each subject, such as Korean, English, and mathematics, had increased, the increase was only a slight one. This result means that changes in the total time invested in private tutoring were not significant enough to affect the increases and decreases for each subject. Eventually, in case of students who had experienced private tutoring at least once, the total time invested in private tutoring tended to remain the same regardless of their grade levels; however, results showed that the time invested in private tutoring was adjusted by necessity. Ultimately, the study showed that once a student started to participate in private tutoring, he or she had to keep participating

\section{The Developmental Change in the Time Invested in}

\section{Private Tutoring And Academic Achievement}

According to the final model selected by the variable, the time invested in private tutoring increased linearly as shown in $<$ Table $4>$. Results showed that the time invested in private tutoring had increased at the rate of .002 every year from the first to the third year. The covariance of private tutoring was shown to be statistically insignificant. This result shows that once private tutoring begins, time invested in private tutoring consistently increases regardless of the initial value of private tutoring.

The value of academic achievement increased at a rate of 1.929 on average. Even if the covariance of private tutoring was statistically insignificant, the covariance of academic achievement was identified to be $-.149 .063(\mathrm{p}<.001)$. Thus, the higher the initial $\log$ values of academic achievement, the greater was the increase in rate of academic achievement over time.

\section{Relations between Changes in the Time Invested in} Private tutoring and Changes in Academic Achievement

The final model verifying the relation structure between changes in private tutoring time and academic achievement using a multivariate latent growth model is shown in $<$ Table $5>$ and $\langle$ Figure $1>$. The suitability of the model was verified as the value of $\chi^{2}$ was found to be 68.778 , and the values of CFI, TLI, and RMSEA were .972, .960, and .038, respectively ${ }^{1}$. The path coefficients between changes in private tutoring time and changes in academic achievement are presented in <Table 5>. The correlation coefficient between the initial value of time invested in private tutoring and the initial value of academic achievement was a path coefficient of .12.282. The path coefficient of the initial value of time invested in private tutoring to change in academic achievement was -3.700 . Thus, the effect of private tutoring on academic achievement was shown to be negative. The path coefficient of the initial value of achievement to changes in time invested in private tutoring was -.011.

\footnotetext{
'Suitability of model is generally considered to be verified in case of CFI $>.90$, TLA $>.90$, RMSEA $<.05$ (Arbuckle,2005)
} 


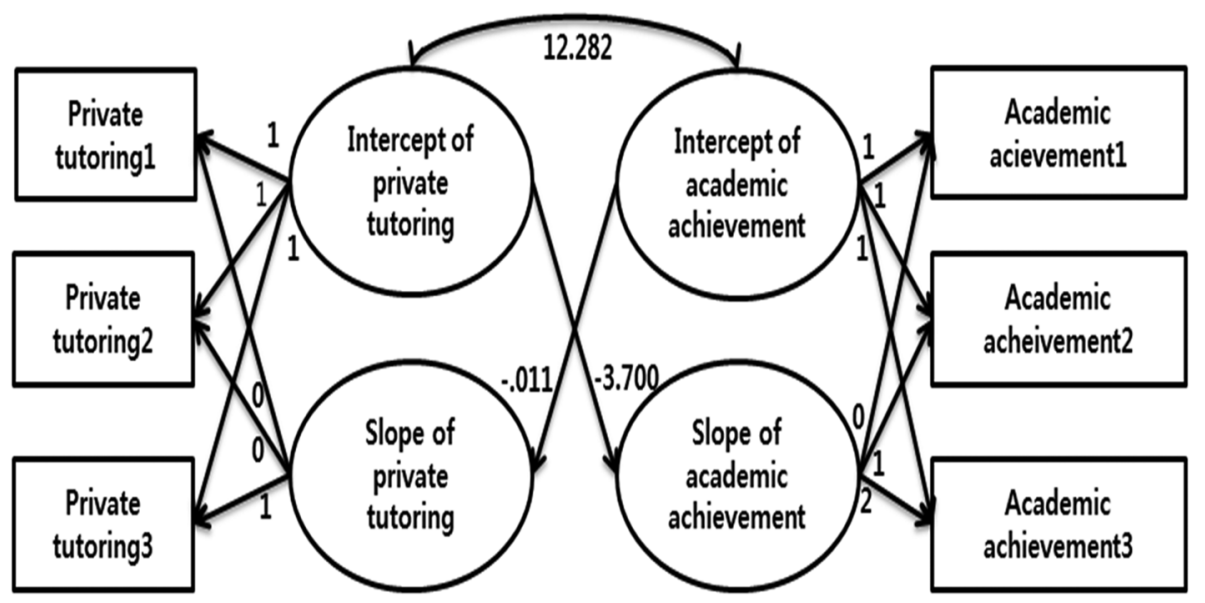

Figure 1. Multivariate Latent Growth Model.

Finally, even though the time invested in private tutoring and academic achievement influenced each other at an early stage, results showed that changes in time invested in private tutoring and changes in academic achievement exerted a negative effect on each other over time. Private tutoring and academic achievement were found to be in a linear relationship. Results showed that the time invested in private tutoring and the academic achievement had increased 0.002 hours and 1.929 hours, respectively, every year. However, the covariance of academic achievement was -149.063 , suggesting that the higher the initial achievement, the lower was the increase. In other words, the higher the academic achievement of a student, the more his or her achievement decreased.

The correlation coefficient between time invested in private tutoring and the initial value of achievement was 12.282 , suggesting that the greater the amount of time invested in private tutoring at an early stage, the higher was the early academic achievement. The effect of time invested in private tutoring at an early stage on changes in academic achievement was -3.700 , and the effect of early academic achievement on changes in time invested in private tutoring was -.011 . These results suggest that the relationship between the values of these changes was negative. Thus, the higher the early achievement, the lower was the rate of change in time invested in private tutoring, and the greater the amount of time invested in private tutoring at the early stage, the lower was the rate of change in academic achievement. Even if the time invested in private tutoring could exert a temporary influence on academic achievement, this study revealed that time invested in private tutoring and academic achievement exerted a negative influence on each other over time. Thus, private tutoring temporarily exerted influence once or twice by helping students prepare for a test, but this effect did not last. However, students and parents who experienced a short-term effect tended to depend on private tutoring more.

\section{Conclusion and Suggestions}

This study examined overall changes in time invested in private tutoring and academic achievement by using data from the first three years of the KYPS. The study also examined how changes in time invested in private tutoring and academic achievement influenced each other through a multivariate latent growth model.

In conclusion, according to the results of this study, private tutoring could improve academic achievement in the short term, but it has a negative effect on academic achievement in the long term. Parents and students are likely to overestimate the effect of private tutoring when they experience temporarily high academic achievement because of tutoring. Accordingly, once parents and students experienced private tutoring, the total time invested in private tutoring tended to remain consistent or 
increase slightly. However, because private tutoring has a negative effect on academic achievement in the long term, academic achievement may not be improved, and it may decrease even if time invested in private tutoring is increased. This finding should not be overlooked, namely that private tutoring might be helpful in the short term at an appropriate time if it is necessary, and that its beneficial effect might be short-lived.

As Kang and Lee (2010) pointed out, the fact that significant investment was made in private tutoring despite the fact that the effect of private tutoring was not proven might have been the case because students and parents did not have any accurate information about the effects of private tutoring and marginal profits. Moreover, it might be difficult to control participation in private tutoring easily because the decision to participate in private tutoring might be influenced by a reference group, even if students and parents know that the effect of private tutoring is small. In addition, it is also possible that academic achievements did not increase as much as investment in private tutoring as the effect of self-learning was decreased because private tutoring replaced selflearning. Therefore, it is necessary to promote realistic information about the effect of private tutoring, discourage the atmosphere of excessive competition, and make multilateral efforts with various needed supports to increase the importance of the positive effects of self-learning in order to prevent an overinvestment in private tutoring.

Korean families overinvest in certain kinds of private tutoring because of a lack of information about the actual benefits of this investment. Consuming private tutoring might not always represent the best strategy for increasing academic performance; however, in a hypercompetitive environment, few families are willing to take the risk of reducing their children's chances of being admitted to elite courses. Therefore, an accurate analysis of the effect of private tutoring needs to be conducted in the Korean government, and an active public relations campaign to increase awareness of these analysis results should be run. The Korean government has been investigating private tutoring since 2007 (Statistical Korea, 2009), and has announced a variety of measures to reduce the costs of private tutoring (Lim et al., 2012). However, the government's corresponding methods have consistently tried to control private tutoring, and the effectiveness of such tutoring has already been lost. Thus, the private tutoring policy should change direction and work towards a realistic estimate of the effects of private tutoring and an active public relations campaign to spread this information.

The limitations of this study are as follows. This study measured the level of participation in private tutoring as the time invested in private tutoring. However, this method did not consider the qualitative aspects of private tutoring. Even if a significant amount of time was invested in private tutoring, there is a strong possibility that the effect of private tutoring was not properly measured in cases where the qualitative aspect of the tutoring was poor. Therefore, considering these points, further studies should examine the qualitative and quantitative aspect at the same time when measuring the level of experience in private tutoring.

Despite the limitations mentioned above, the significance of this study is the longitudinal design, which had not been present in the previous studies. This study measured academic achievement with objective data, used average values for all the subjects in terms of time invested in private tutoring, and systematically investigated the relationship between academic achievement and private tutoring.

\section{REFERENCES}

Arbuckle, J. L (2005). $\operatorname{Amos}^{T M} 6.0$ User's Guide, Chicago, SPSS, Inc.

Baker, D. P., Akiba, M., LeTendre, G., \& Wiseman, A. W. (2001) Worldwide Shadow Education: Outsideschool learning, Institutional Quality of Schooling, and Cross-National Mathematics Achievement, Educational Evaluation and Policy Analysis, 23(1), 1-17.

Baker, D., \& LeTendre, G.(2005). National Differences, Global Similarities: World Culture and the Future of Schooling. Plo Alto, Stanford University Press.

Baker, G. S. (1993). Human Capital: A Theoretical and 
Empirical Analysis, with Special Reference to Education (3rd ed.). The National Bureau of Economic Research.

IL: The University of Chicago Press.

Ban, S. J., Jeong, S. S., Yang, S. K., \& Oh, H. O. (2005). Analysis of the Effect of Tutoring on Academic Achievement, Korea Research Institute for Vocational Education and Training

Banerjee, A. V., Cole, S., Duflo, E., \& Linden, L. (2007). Remedying education: Evidence from two randomized experiments in India. Quarterly Journal of Economics, 122(3), 1235-1264

Bray, M., \& Kwok, P. (2003). Demand for private supplementary tutoring: Conceptual considerations and socio-economic patterns in Hong Kong. Economics of Education Review, 22(6), 611-620.

Choi, J. A. (2011). Longitudinal Association of adolescents' perceived parental support, self-control, and school adjustment-A multivariate latent growth model-, Social Science Research Review, 27(3), 189-212.

Dang, H. -A. (2007). The determinants and impact of private tutoring classes in Vietnam. Economics of Education Review, 26(6), 684-699.

Dore, R. (1976). The Diploma Disease: Education, Qualification, and Development. Berkely, CA: University of California Press.

Foondun, A. R. (2002). The issue of private tuition: An analysis of the practice in Mauritus and selected south-east Asian countries. International Review of Education, 48(6), 485-515.

Hahn, D. D., Sung, B. C., \& Gik, I. J (2001). A study on the comparison between the effects of private tutoring versus in-school education on academic achievement of high school students, Sociology of Education, 11(1), 33-54.

Ireson, J. (2004). Private tutoring: How prevalent and effective is it? London Review of Education, 2(2), 109122.

Kang, C. E., \& Lee, S. H. (2010). An Economic Analysis of Private tutoring in Korea, Korean Education Developmental Institute.

Kim, H. J. (2007). Analyzing the structure of variables affecting on private tutoring expense, The Journal of Educational Administration, 22(1), 27-45.
Lee, E. W. (2006). Economics analysis of Private education expenditure in Korea. Journal of Economic Studies, 22(2), 1-31.

Lee, J. H. (2002). Family Environment, Private Tutoring, and School Grades, The Korean Journal of Sociology, 36(6), 195-212.

Lee, K., \& Kwon, Y. (2011). The effect of private tutoring expenses and hours on academic achievement: quantile regression approach. The Journal of Economics and Finance of Education, 20(3), 99-133.

Lee, S. J. (2007). An Socio-Psychological Approach to the Cause of Shadow Education in South Korea, The Journal of Educational Administration, 25(4), 455484

Lee, S. J., \& Im, H. J. (2009). An Analysis of the Effect of Private Tutoring Expenditure on Middle School Students' Achievement. The Journal of Economics and Finance of Education, 18(1), 141-166

Lim, S. T., Eo, S. M., Jo, Yo. M. (2012). Development and validation of a scale of parents' motivation to participate in private education markets for their children, Journal of Education Sciences, 43(4), 271-296.

Nam, K. K. (2008). The Relationship between private tutoring time and academic achievement: international comparative analysis using 2003 PISA data. The Korean Journal of Economics, 15(1), 55-90.

Ono, H. (2007). Does examination hell pay off? A cost-benefit analysis of "ronin" and college education in Japan. Economics of Education Review, 26, 271-284.

Paik, I. W. (1999). Economic understanding of tutoring, Korean Journal of Educational Research, 37(4), 391305.

Park, C. N., \& Do, J. S. (2005). The effect of parent's socio-economics status on academic achievement. Social Welfare Policy, 22, 281-303

Park, H. J. (2010). Longitudinal analysis of the relationship between private tutoring expenses and students' achievement. Journal of Educational Evaluation, 23(4), 887-907.

Park, J. J. (2010). Examination of the relationship between private tutoring and its subjective effect by autoregressive cross-lagged model: multi-group 
analysis across income, The Journal of Educational Administration, 29(3), 149-168.

Shin, I. C., \& Kim, K. H. (2010). Effect of academic achievement on the use of private tutoring in Korea, Korean Journal of Sociology of Education, 20(1), 127-150.

Shon, H. K., Lee, D. H., Jang, S. H., \& Kim, T. K. (2010). Longitudinal relationship among private tutoring, student-parent conversion, and student achievement, Korean Journal of Education policy, 7(1), 23-41.

Smyth, E. (2009). Buying your way into college? Private tuition and the transition to higher education in Ireland. Oxford Review of Education, 35(1), 1-22.

Statistics Korea (2009). Private Education Survey, Seoul; Statistics Korea

Stevenson, D. L., \& Baker, D. P. (1992). Shadow education and allocation in formal schooling: Transition to university in Japan. American Journal of Sociology, 97(6), 1639-1657.
Sung, K., \& Kim, J. (2010). An comparative study on the relationship between private experience and high school students' academic science achievement: Korea, Finland and Japen, Korean Journal of Sociology of Education, 20(1), 103-126.

Suryadarma, D., Suryahadi, A., Sumarto, S., \& Rogers, F. H. (2006). Improving student performance in public primary schools in developing countries: Evidence from Indonesia. Education Economics, 14(4), 401-429.

Yang, J. H., \& Kim, K. K. (2003). Effects of middle school organization on academic tutoring achievement in Korea: An HLM analysis of TIMSS-R. Korean Journal of Sociology of Education, 13(2), 165184.

Received April 11, 2013

Revised May 27, 2013

Accepted June 10, 2013 